\title{
Does an Information Technology Investment Contribute to Company Performance: a Further Examination of the Productivity Paradox
}

\author{
Dr. Marc Sollosy \\ Dr. Rick Weible \\ Marshall University \\ Lewis College of Business \\ Brad D. Smith Schools of Business \\ One John Marshall Drive \\ Huntington, WV 25755, USA
}

\begin{abstract}
This article continues the discussion examining IT's contribution on firm performance. Byrnjolfsson (1993) identified what is known as the "productivity paradox" and posited a number of reasons for it. Carr (2003) added fuel by suggesting IT is ubiquitous and provides no significant firm advantage. This study does identify that industry type and size matters. Utilizing the position of CIO, or similar, as a proxy for IT emphasis, the study finds that non-IT intensive organizations, with annual sales less than \$101million do achieve performance advantages over firms without an IT emphasis. The implication being that the debate is far from over.
\end{abstract}

Keywords: productivity, paradox, performance, utility, CIO

\section{Introduction}

The focus of the authors is to examine the impact of IT on firm performance, when compared to other firms within the same industry. This remains an important issue because firms annually expend varying, and often significant, amounts of resources on Information Technology (IT) related activities. While it is nearly impossible to discount the need for IT in today's business environment, the impact upon company performance from these investments is the subject of much on-going debate. The dyadic nature of the debate has left the issue far from resolved (Bhatt \& Grover, 2005; Ravinchandran \& Lertwongsatien, 2005). Given that a definitive answer may remain elusive, an increasing awareness of the impact of IT on firm performance visa vie competitors and industry norms should aid firms in reconciling some of the dissonance associated with the investment decision. The measure of the contribution of IT to firm performance has been, and remains controversial. Byrnjolfsson (1993) identified this "productivity paradox" and posited potential reasons for the measurement controversy, including: mismeasurement of outputs and inputs, lags due to learning and adjustment, redistribution and dissipation of profits, and mismanagement of information and technology. The absence of good qualitative measures for the value created by IT makes the IT professional's job of justifying investments particularly difficult. Nicholas Carr, in his Harvard Business Review article, IT Doesn't Matter (2003) adds fuel to the debate by suggesting IT provides no significant advantage to firms and thus no competitive advantage. Other researchers show that indeed IT contributes to improvements in organizational performance (Brynjolfsson, E. \& Hitt, 1996; Kohli \& Devaraj, 2003). Part of the debate may be due to the breadth and extent of the IT business contribution being dependent upon a variety of factors such as; the type of IT, management practices, and organizational structure (Brynjolfsson, E., Hitt, \& Yang, 2002; Dewan \& Kraemer, 2000). The extant literature on the topic includes contributions for a number of academic disciplines, including; information systems, economics, strategy, accounting, and operations research.

Given the controversy created in corporate boardrooms regarding the impact on firm performance associated with IT investments; does IT become relegated to the domain of a necessary infrastructural expense providing no on-going competitive advantage for the firm or is it a source of differentiation and advantage? Carr (2003) posits that IT is ubiquitous, increasingly inexpensive, and accessible to all firms and therefore, cannot provide differential advantage to any firm. He bases his argument partially on the resource based view (RBV) postulate that it is scarcity, not ubiquity that is a necessary condition for supernormal rent generation. Other researchers have positioned the issue in terms of IT capabilities and argue that such capabilities can, and often do, create uniqueness and therefore provide firms with a competitive advantage (Bhatt \& Grover, 2005; Mata, Fuerst, \& Barney, 1995). 
In fact, these researchers often evoke RBV as the foundation for their support of ITs contribution to firm performance (Bharadwaj, 2000; Dehning \& Stratopoulos, 2003; Mata et al., 1995; Santhanam \& Hartono, 2003) by arguing that IT related organizational capabilities tend to be heterogeneously distributed among firms, thus leading to differentiated business values to firms by improving organizational efficiencies, effectiveness, and uniqueness. It is becoming increasingly recognized that the RBV competitive advantage of an organization does not lie entirely in merely the owning of the resources as such. Rather how those resources are configured within the company by management and how they are leveraged is the differential (Miller, 2017). This resource management entails the comprehensive process of structuring, bundling, and leveraging the organization's resources with the explicit purpose of creating value and competitive advantage (Sirmon, Hitt, Ireland, \& Gilbert, 2010). As such, the CIO is an integral member of the top management team who serves to actively manage the integration and utilization of the IT related resources to aid the organization in achieving its strategic objectives.

A considerable amount of research, beginning in the early 1980's, has been focused on the strategic impact of IT and its potential for creating firm competitive advantage (McFarlan, Jordan, \& Wurmfeld, 1984; Piccoli \& Ives, 2005; Porter $\&$ Millar, 1985). This work supports the conclusion that IT can lead to the creation of competitive advantage through efficiency and effectiveness improvements, differentiation, and channel domination (Sethi \& King, 1994). Running along similar lines as RVB, the IT dependent strategic initiative view consists of identifiable firm moves dependent upon the use of IT designed to lead to sustained improvements in a firm's competitive position (Ross, Beath, \& Goodhue, 1996). This view does not merely entail building computer systems or applications that according to Carr (2003) generate competitive advantage until it is successfully replicated. Rather it encompasses the totality of an activity system, dependent upon IT at its core that supports the creation of economic value (Brandenburger \& Stuart Jr, 1996). This study utilizes the lens of sustainable competitive advantage, RBV (Barney, 1986; Wernerfelt, 1984), and dynamic capabilities (Eisenhardt \& Martin, 2000; Zahra \& Nielsen, 2002) to examine firm performance. For purposes of this study, competitive advantage means performing business activities better than the industry average. Differences in the performance of these activities or the activities actually chosen to perform serve as the basis of competitive advantage (Dehning \& Stratopoulos, 2002).

The authors posit that IT does provide a basis for strategic differential and competitive advantage. That the CIO serves as the most senior management team member whose principle responsibility is to provide the oversight in the structuring, bundling and leveraging of the IT related resources. While the impact of IT may differ between industries groups, it does serve as an important differentiator within industry classes. One measure of an organization's view of the significance of IT is the role of IT related management within the organization. The authors intend to utilize the Chief Information Officer (CIO) as a proxy for evaluating the strategic import of IT within the organization. It is the author's position that organizations with a CIO or equivalent will out preform their peers that do not identify such a role within the organization. A review of the literature will be utilized to build a theoretical framework to examine the impacts and contributions of IT to firm performance. Second, the methodology utilized in the study will be presented, along with a presentation of the findings. Finally, the ramifications of the findings, from the academic perspective as well as the implications to the practitioner, will be discussed.

\section{Literature Review}

The role IT plays and its impact as a strategic differentiator varies between industries and companies within the same industry. The differences that occur between industries are far easier to observe given the heterogeneous conditions that exist. The needs for and application of IT dramatically differ between the financial services sector and say retail or manufacturing. Arguably, the disparate business functions and conditions between these industries leads to differing focuses and impact of IT. The question of IT's strategic impact within a single or homogeneous industry is a question that has been long debated. The productivity paradox (Brynjolfsson, E., 1993; Brynjolfsson, E. \& Hitt, 1998; Brynjolfsson, Erik \& Hitt, 2000) and Carr (2003) posit that IT provides no significant competitive advantage. Conversely, Brynjolfsson, et al (2002) and Dewan and Kraemer (2000) recognize that the IT strategic business contribution is dependent upon a variety of factors. These include the type of IT being deployed; inwardly focused, i.e., infrastructural, or outwardly focused, i.e., customer service, B2B, B2C, etc. Organizational structure and how IT is positioned within the organization can provide further insight into the strategic placement and importance within the organization. A key indicator of the role of IT within the organization is designation and reporting relationship of the individual most responsible for leading IT. The organizational Chief Information Officer (CIO) emerged in the early 1980's (Synnott \& Gruber, 1981) to facilitate responding to rapidly changing technology, changes requiring alteration of market orientation, and competition requiring new delivery channels and services, to name a few. In essence this began the emergence of the 'information economy' (Benjamin, Charles, \& Rockart, 1985). 
This strategy-structure paradigm postulates that organizations with a (CIO) or equivalent will out preform those organizations where the responsibility for IT is relegated to a lower level in the organization's management hierarchy (Banker, Hu, Pavlou, \& Luftman, 2011). Banker et al (2011) postulate that organizations whose CIO who report to the organization's Chief Executive Officer (CEO) will perform at a higher level than those organizations where the CIO reports to the Chief Financial Officer (CFO). The CIO reporting relationship is indicative on how critical IT is to the organization's culture and strategy (Benjamin et al., 1985; Jones, Taylor, \& Spencer, 1995). Banker et al (2011) posit that organizations that view IT as a strategic asset tend to have their CIOs report directly to the CEO, whereas organizations that do not view IT as a strategic asset tend to have their CIOs, if they even have one, report to the CFO or lower. The latter would be in keeping with the "plumbing" orientation towards IT.

The CIO position has become increasingly more important as IT increasingly plays a more central role in the organization's processes and strategy (Banker et al., 2011; Raghunathan, B. \& Raghunathan, 1989; Raghunathan, Bhanu \& Raghunathan, 1993). Where the CIO reports, and even if there is a CIO, has implications for the organization's performance. Hambrick and Mason's (1984) "upper echelon" theory postulates that an organization's top management team (TMT) can affect performance. An organization's IT structure and reporting relationships can have a significant impact on an organization's performance (Csaszar \& Clemons, 2006).

The 'ideal' CIO reporting relationship remains somewhat unclear in both the academic and practioneer IT literature (Banker et al., 2011). "The fact that the IT manager is distant from the CEO is an indication that the organization does not place a high value on IT and IT planning" (Watson, 1990, p.228). Rughunathan and Rughunathan (1989) found that the impact of the CIO declines significantly when there is more than two levels between them and the CEO. This decline in impact is a further indication of the lack of strategic importance placed on IT within the organization. Applegate and Elam (1992) and Luftman and Kempaiah (2007) present the CIO's power and the role of IT within the organization as a function of the reporting relationship between the CIO and CEO. The success and influence of IT is more likely if the CIO is closer to the CEO (Armstrong \& V, 1999).

An organization's CIO contribute to value creation by increasing the strategic foresight of the TMT. Karahanna and Chen (2006) and Preston and Karahanna (2009) found that organizations with effective CIOs consistently outperform their industry competitors. The CIO's reporting structure is reciprocal with the organization's orientation towards IT. In a strategic orientation, the CIO is a member of the TMT and is actively involved in the organization's strategic planning (Reich \& Nelson, 2003). Ives and Olson (1981) suggest that in the operational IT orientation the CIO is only responsible for leading the IT function, offering IT support and managing less risky, non-strategic, projects. Banker et al (2011) argue that for differentiators focusing on innovation and customer intimacy, IT initiatives are primarily aimed at enhancing new product development and customer intimacy. IT initiatives in product development, such as tools used to increase collaboration, i.e., cross-functional integration among marketing, $R \& D$, and engineering to develop original products or services (Pavlou \& Fygenson, 2006). Supply chain IT initiatives such as real-time intelligence and global visibility systems focusing on customer intimacy by dynamically adjusting to changing customer needs (Rai, Im, \& Hornyak, 2009). Additionally, IT initiatives such as data mining for market intelligence that can be used to personalize marketing efforts and meet changes in customer needs (Farrell, Terwilliger, \& Webb, 2003). The inclusion of a CIO in the organization's TMT is an indication of an IT strategy. Without a clear IT strategy, the actual contribution of IT to the organization's performance is most probably the result of serendipity (Galliers, 2011; Leidner, Lo, \& Preston, 2011). This alignment of IT to the strategic alignment of the organization has focused on the degree IT is strategic and structural (Reich \& Benbasat, 1996; Venkatraman, Henderson, \& Oldach, 1993) or even more recently, informational (Chan, 2002), aligned with the organization.

In keeping with the alignment-fit view (Mintzberg, 1990) the importance of aligning the organization's IT strategy with the organization's strategic view and structure has been widely established (Govindarajan, 1989; Hambrick \& Mason, 1984). Mintzberg (1987) attempts to clarify the concept of strategy by offering five definitions commonly known as the five Ps for strategy. He identifies strategy as; (1) a plan - an intended course of action, (2) a ploy - a specific maneuver to outwit a competitor, (3) a pattern - a stream of realized ploys, (4) a position - a means of matching an organization with its external environment to find the proper market niche, and (5) a perspective - a shared view of the organization that is ingrained within and among its members. Chen et al. (2010) adopts Mintzberg's fifth definition and defines IT strategy as the "Organizational perspective on the investment in, deployment, use, and management of information systems" (p. 237). Leidner, et al (2011) suggest that merely defining IT strategy as a perspective does not imply that it is necessarily a realized outcome or a set of formally planned or intended actions on the part of the organization. 
However, the clearly articulated role of CIO and the resulting integration of a shared view among the organization's TMT helps ensure that all organizational members have a similar orientation (Tai \& Phelps, 2000). This in turn leads to general consensus among the TMT regarding the role of IT in relation to the rest of the organization (Pyburn, 1983). It is through this conception and implementation whereby IT is inextricably incorporated in to the organizations overall business strategy (Galliers, 2011; Leidner et al., 2011).

Building upon this foundation, the authors posit that the existence of a $\mathrm{CIO}$ or similar role within the organization will enhance the organization's performance. Because the presence of a CIO exemplifies the significance of IT, and by extension an IT strategy, within the organization it is not farfetched that like an organization's overall business strategy, IT should also have an impact on organization level performance outcomes. Given that IT as a business unit typically accounts for a large percentage of an organization's capital expenditures, the IT strategy, as exemplified by the presence of a CIO, would be pursuing activities and innovations supporting the business's innovations.

\section{Methods}

The examination of the role of IT on organizational performance was conducted by analyzing data from a commercially available dataset. Performance data for the companies classified as industrial capital goods within the construction and engineering industry in the U.S. was extracted from Standard \& Poor's Capital I.Q. database. This study utilized the presence, or lack of, a CIO as a proxy or dummy variable for an organization's level of commitment and investment in IT. The dataset utilized comprised 20,726 companies. The companies were broken out by sales volume. 19,846 of the companies had sales volume between $\$ 10$ million and $\$ 100$ million, with the majority, 18,852 of the companies having annual sales of $\$ 50$ million or less. The remaining 539 companies have annual revenue of between $\$ 50$ million and $\$ 100$ million. The remaining 862 companies in the sample were comprised of 593 companies with sales between $\$ 101$ million and $\$ 250$ million, 156 companies with sales between $\$ 252$ million and $\$ 500$ million. Only 167 companies in the sample had annual sales in excess of $\$ 501$ million. IT is an established precept such that firms in the same or similar industry grouping display significant heterogeneity in terms of their productivity. In order to account for the effect organization size has on performance measures, the authors divided the organization's total revenue by the total number of employees. The resulting ratio served as the measure of organizational success. While an organization's total revenue is universally viewed as a measure of success, the authors used the ratio to further refine the performance measure. Mahmood and Mann (2005) employing the results of canonical correlation suggest that organizational strategic and economic performance measures are positively affected by investments in information technology related activities. Another measure is organizational productivity. Specifically, labor productivity. In general, organizational efficiency is exemplified as doing more with less. We used the adjusted revenue per employee as a proxy measure for labor productivity.

\section{Findings}

The purpose of this study was to further examine the IT productivity paradox by asking the question: Do organizations that view IT as a tool for providing a competitive advantage outperform organizations that do not? The authors utilized the presence of a CIO or similar position within the organization as the dependent variable. Organizational performance was the independent variable. This variable is the derived as the ratio resulting from dividing total revenue by total number of employees. A one-way analysis of variance (ANOVA) was conducted to evaluate the relationship between the presence of a CIO or similar position and superior organizational performance, where the size of the organization was broken out into five levels, in terms of annual sales volume. Results found that for organizations with $\$ 50$ million or less in annual revenue, the presence of a CIO within the organization had a significant impact on performance, $\mathrm{F}(90,18853)=1.77, \mathrm{p}=.000$. The presence of a CIO was also significant for organizations with annual sales of $\$ 50$ million to $\$ 100$ million, $F(49,1011)=1.804, p=.005$. However, at levels of more the $\$ 101$ million the presence, or lack thereof, has no significance on company performance. All results are presented in Table 1 below.

Table 1 - ANOVA Results

\begin{tabular}{|l|l|l|l|l|l|l|}
\hline $\begin{array}{l}\text { Size } \\
\mathbf{\$ ( 0 0 0 , 0 0 0})\end{array}$ & & $\begin{array}{l}\text { Sum of } \\
\text { Square }\end{array}$ & df & Mean Square & F & Sig. \\
\hline $\mathbf{\$ 0}-\mathbf{\$ 5 0}$ & Between Group & 53,179 & 8525 & .0006 & 1.770 & .000 \\
\hline & Within Group & 36,391 & 10327 & .004 & & \\
\hline & Total & 89,570 & 18852 & & & \\
\hline $\mathbf{\$ 5 1 - \mathbf { \$ 1 0 0 }}$ & Between Group & 31,732 & 862 & .037 & 1.804 & .005 \\
\hline & Within Group & 100 & 49 & .020 & & \\
\hline
\end{tabular}




\begin{tabular}{|l|l|l|l|l|l|l|}
\hline & Total & 32,732 & 911 & & & \\
\hline $\mathbf{\$ 1 0 1}-\mathbf{\$ 2 5 0}$ & Between Group & 39,748 & 525 & .076 & 1.590 & .158 \\
\hline & Within Group & 667 & 14 & .048 & & \\
\hline & Total & 40,415 & 539 & & & \\
\hline $\mathbf{\$ 2 5 1}-\mathbf{\$ 5 0 0}$ & Between Group & 18,191 & 155 & .117 & & \\
\hline & Within Group & 0.0 & 1 & 0.0 & & \\
\hline & Total & 18,191 & 156 & & & \\
\hline $\mathbf{\$ 5 0 0 +}$ & Between Group & 25,905 & 166 & .156 & & \\
\hline & Within Group & 0.0 & 1 & 0.0 & & \\
\hline & Total & 25,905 & 167 & & & \\
\hline
\end{tabular}

\section{Discussion}

The productivity paradox (Brynjolfsson, E., 1993) continues to remain unresolved. Carr's (2003) arguments still seem to have credence. However, when one factors in the size of the organization, there clearly is a jumping off point where size no longer seems to matter. It appears that larger organizations, those with annual sales exceeding \$101 million find no performance differential attributable to the role of a CIO. At that level of sales, IT may be so ingrained into the on-going operations of the organization as to become ubiquitous. The resources, and their management, attributable to IT become disseminated throughout the very DNA of the organization. The larger the organization, the more likely that the CIO, while remaining a critical member of the top management team, becomes a more integrated part of the total organization. As such, the impact of the CIO and IT becomes more difficult to isolate and measure. The CIO while an important member of the top management team, does not necessarily have the lead role in facilitating strategic orientation and operation. Smaller organizations, with sales less than $\$ 100$ million annually, have a tendency to isolate and focus on specific resources such as IT. In these instances, the CIO's role and visibility is often much greater. Smaller firms often find themselves more frequently and aggressively reconfiguring resources in relation to changes in their environments. While this reconfiguration is referred to dynamic capabilities (Eisenhardt \& Martin, 2000; Teece, 2007), the role of the CIO in this process may well be analogues to, if not the conductor of a symphony orchestra, the first seat in the string or woodwind section of that orchestra. In such a position, they play a significant role in the overall quality of the output of the organization. As is evident from the findings, the debate over the role of IT and the $\mathrm{CIO}$ is far from over. As the nature of technology continues to change. As IT continues to permeate into most all aspects of life, both personal and business, its importance and role seeks new levels. As a result, IT and the role of the CIO may well be entering into the next chapter of its story.

\section{References}

Applegate, L. M., \& Elam, J. J. (1992). New information systems leaders: A changing role in a changing world. MIS Quarterly, 16(4), 469-490.

Armstrong, C. P., \& V, S. (1999). Information technology assimilation in firms: The influence of senior leadership and IT infrastructures. Information Systems Research, 10(4), 304-327.

Banker, R. D., Hu, N., Pavlou, P. A., \& Luftman, J. (2011). CIO reporting structure, strategic positioning, and firm performance. MIS Quarterly, 35(2), 487-504.

Barney, J. B. (1986). Strategic factor markets: Expectations, luck, and business strategy. Management Science, 32(10), 1231-1241.

Benjamin, R. I., Charles, D.,Jr, \& Rockart, J. F. (1985). Changing role of the corporate information systems officer. MIS Quarterly, 9(3), 177-188.

Bharadwaj, A. S. (2000). A resource-based perspective on information technology capability and firm performance: An empirical investigation. MIS Quarterly, 24(1), 169-196.

Bhatt, G. D., \& Grover, V. (2005). Types of information technology capabilities and their role in competitive advantage: An empirical study. Journal of Management Information Systems, 22(2), 253-277.

Brandenburger, A. M., \& Stuart Jr, H. W. (1996). Value- based business strategy. Journal of Economics \& Management Strategy, 5(1), 5-24.

Brynjolfsson, E. (1993). The productivity paradox of information technology. Communications of the ACM, 36(12), 77. Brynjolfsson, E., \& Hitt, L. M. (1998). Beyond the productivity paradox. Communications of the ACM, 41(8), 55.

Brynjolfsson, E., \& Hitt, L. (1996). Paradox lost? firm-level evidence on the returns to information systems spending. Management Science, , 541-558. 
Brynjolfsson, E., Hitt, L. M., \& Yang, S. (2002). Intangible assets: Computers and organizational capital. Brookings Papers on Economic Activity, 2002(1), 137-181.

Brynjolfsson, E., \& Hitt, L. M. (2000). Beyond computation: Information technology, organizational transformation and business performance. The Journal of Economic Perspectives, 14(4), 23-48.

Carr, N. G. (2003). IT doesn't matter. Harvard Business Review, 81(5), 41-49.

Chan, Y. E. (2002). Why haven't we mastered alignment? the importance of the informal organization structure. MIS Quarterly Executive, 1(2), 97-112.

Chen, D. Q., Mocker, M., Preston, D. S., \& Teubner, A. (2010). Information systems strategy: Reconceptualization, measurement, and implications. MIS Quarterly, 34(2), 233-259.

Csaszar, F., \& Clemons, E. (2006). Governance of the IT function: Valuing agility and quality of training, cooperation and communications.

Dehning, B., \& Stratopoulos, T. (2002). DuPont analysis of an IT-enabled competitive advantage. International Journal of Accounting Information Systems, 3(3), 165-176. doi:10.1016/s1467-0895(02)00032-5

Dehning, B., \& Stratopoulos, T. (2003). Determinants of a sustainable competitive advantage due to an IT-enabled strategy. The Journal of Strategic Information Systems, 12(1), 7-28. doi:10.1016/s0963-8687(02)00035-5

Dewan, S., \& Kraemer, K. L. (2000). Information technology and productivity: Evidence from country-level data. Management Science, , 548-562.

Eisenhardt, K. M., \& Martin, J. A. (2000). Dynamic capabilities: What are they? Strategic Management Journal, 21(10-11), 1105-1121. doi:10.1002/1097-0266(200010/11)21:10/113.0.co;2-e

Farrell, D., Terwilliger, T., \& Webb, A. P. (2003). Getting IT spending right this time. McKinsey Quarterly, (2), 118129.

Galliers, R. D. (2011). Further developments in information systems strategizing: Unpacking the concept. The Oxford Handbook of Information Systems: Critical Perspectives and New Directions.Oxford University Press, Oxford, , 329-345.

Govindarajan, V. (1989). Implementing competitive strategies at the business unit level: Implications of matching managers to strategies. Strategic Management Journal, 10(3), 251-269.

Hambrick, D. C., \& Mason, P. A. (1984). Upper echelons: The organization as a reflection of its top managers. Academy of Management Review, 9(2), 193-206.

Ives, B., \& Olson, M. H. (1981). Manager or technician? the nature of the information systems manager's job. MIS Quarterly, 5(4), 49-63.

Jones, M. C., Taylor, G. S., \& Spencer, B. A. (1995). The CEO/CIO relationship revisited: An empirical assessment of satisfaction with IS. Information \& Management, 29(3), 123-130.

Karahanna, E., \& Chen, D. (2006). Give your CIO time: An empirical analysis of CIO role effectiveness and firm performance. Unpublished manuscript.

Kohli, R., \& Devaraj, S. (2003). Measuring information technology payoff: A meta-analysis of structural variables in firm-level empirical research. Information Systems Research, 14(2), 127.

Leidner, D. E., Lo, J., \& Preston, D. (2011). An empirical investigation of the relationship of IS strategy with firm performance. The Journal of Strategic Information Systems, 20(4), 419-437.

Luftman, J., \& Kempaiah, R. (2007). An update on business-it alignment: "A line" has been drawn. MIS Quarterly Executive, 6(3), 165-177.

Mahmood, M. A., \& Mann, G. J. (2005). Information technology investments and organizational productivity and performance: An empirical investigation. Journal of Organizational Computing and Electronic Commerce, $15(3), 185-202$.

Mata, F. J., Fuerst, W. L., \& Barney, J. B. (1995). Information technology and sustained competitive advantage: A resource-based analysis. MIS Quarterly, 19(4), 487-505.

McFarlan, F. W., Jordan, C., \& Wurmfeld, C. (1984). Information technology changes the way you compete. Harvard Business Review, 62(3), 98-103.

Miller, D. (2017). Challenging trends in configuration research: Where are the configurations? Strategic Organization, , 1476127017729315.

Mintzberg, H. (1987). Crafting strategy.

Mintzberg, H. (1990). The design school: Reconsidering the basic premises of strategic management. Strategic Management Journal, 11(3), 171-195.

Pavlou, P. A., \& Fygenson, M. (2006). Understanding and predicting electronic commerce adoption: An extension of the theory of planned behavior. Management Information Systems Quarterly, 30(1), 115. 
Piccoli, G., \& Ives, B. (2005). Review: IT-dependent strategic initiatives and sustained competitive advantage: A review and synthesis of the literature. MIS Quarterly, 29(4), 747-776.

Porter, M. E., \& Millar, V. E. (1985). How information gives you competitive advantage. Harvard Business Review, 63(4), 149-160.

Preston, D., \& Karahanna, E. (2009). How to develop a shared vision: The key to IS strategic alignment. MIS Quarterly Executive, 8(1), 1-8.

Pyburn, P. J. (1983). Linking the MIS plan with corporate strategy: An exploratory study. MIS Quarterly, , 1-14.

Raghunathan, B., \& Raghunathan, T. S. (1989). Relationship of the rank of information systems executive to the organizational role and planning dimensions of information systems. Journal of Management Information Systems, , 111-126.

Raghunathan, B., \& Raghunathan, T. S. (1993). Does the reporting level of the information systems executive make a difference? The Journal of Strategic Information Systems, 2(1), 27-38. doi:10.1016/0963-8687(93)90020-b

Rai, A., Im, G., \& Hornyak, R. (2009). How CIOs can align IT capabilities for supply chain relationships.

Ravinchandran, T., \& Lertwongsatien, C. (2005). Effect of information systems resources and capabilities on firm performance: A resource-based perspective. Journal of Management Information Systems, 21(4), 237-276.

Reich, B. H., \& Benbasat, I. (1996). Measuring the linkage between business and information technology objectives. MIS Quarterly, 20(1), 55-81.

Reich, B. H., \& Nelson, K. M. (2003). In their own words: CIO visions about the future of in-house IT organizations. ACM SIGMIS Database, 34(4), 28-44.

Ross, J. W., Beath, C. M., \& Goodhue, D. L. (1996). Developing long-term competitiveness through information technology assets. Sloan Management Review, 38(1), 31-42.

Santhanam, R., \& Hartono, E. (2003). Issues in linking information technology capability to firm performance. MIS Quarterly, 27(1), 125-153.

Sethi, V., \& King, W. R. (1994). Development of measures to assess the extent to which an information technology application provides competitive advantage. Management Science, 40(12), 1601-1627.

Sirmon, D. G., Hitt, M. A., Ireland, R. D., \& Gilbert, B. A. (2010). Resource orchestration to create competitive advantage: Breadth, depth, and life cycle effects. Journal of Management, doi:10.1177/0149206310385695

Synnott, W. R., \& Gruber, W. H. (1981). Information resource management: Opportunities and strategies for the 1980s John Wiley \& Sons, Inc. New York, NY, USA.

Tai, L. A., \& Phelps, R. (2000). CEO and CIO perceptions of information systems strategy: Evidence from hong kong. European Journal of Information Systems, 9(3), 163-172.

Teece, D. J. (2007). Explicating dynamic capabilities: The nature and microfoundations of (sustainable) enterprise performance. Strategic Management Journal, Vol. 17, 28, 1319.

Venkatraman, N., Henderson, J. C., \& Oldach, S. (1993). Continuous strategic alignment: Exploiting information technology capabilities for competitive success. European Management Journal, 11(2), 139-149. doi:10.1016/0263-2373(93)90037-I

Watson, R. T. (1990). Influences on the IS manager's perceptions of key issues: Information scanning and the relationship with the CEO. MIs Quarterly, , 217-231.

Wernerfelt, B. (1984). A resource-based view of the fiirm. Strategic Management Journal, 5, 171-180.

Zahra, S. A., \& Nielsen, A. P. (2002). Sources of capabilities, integration and technology commercialization. Strategic Management Journal, 23(5), 377. doi:10.1002/smj.229 